\title{
土被りの浅い砂質地山トンネルの補助工法に関する模型試験
}

\section{MODEL TEST ON PREREINFORCEMENT OF SHALLOW TUNNEL IN SANDY GROUND}

\author{
福島 伸二*・望月美登志** ·香川和夫** ・ 横 山 章*** \\ By Shinji FUKUSHIMA, Yoshitoshi MOCHIZUKI, Kazuo KAGAWA and Akira YOKOYAMA
}

\begin{abstract}
In order to excavate a shallow tunnel in sandy ground, it is necessary to stabilize the ground surrounding the opening and prevent a surface settlement. For the purpose, an appropriate prereinforcement should be applied to improve the ground conditions. However, it has not been fully clarified an effect and a reinforcing mechanism of the prereinforcement method. In this paper, a series of model tests was performed on sandy ground to investigate the reinforcing mechanism of prereinforcement method using steel bolts. It was found the following from the model tests.
\end{abstract}

(1) The reinforcing mechanism of bolting reinforcement is the restraint of deformation of ground by the frictional force generated between the soil and steel bolt placed in the ground.

(2) If the bolts were placed in the direction of the minimum principal strain, the effect of preventing the deformation is most effective.

Keywords : tunnel, prereinforcement, model test, sandy ground

\section{1. まえがき}

都市部におけるトンネル掘削の特徵は土被りが浅いこ と, 地山が砂質土のような未固結な地盤であること, さ らに地表面上には住宅, 事務所などの構造物があること である.このような土被りの浅い未固結地山を NATM 工法で掘削するには切羽周辺の地山を安定させ地表面の 沈下を最小限に抑える必要がありここのためには事前に 適切な補助工法を施工して安全に掘削できるような状態 に地山を補強しなければならない。ここでいう補助工法 は通常の施工法で採用される機械設備で対処し得るボル 卜, 鋼矢板などを用いた切羽の天端部および鏡部の安定 を目的とした地山の補強法であるが,この補助工法の地 山補強メカニズムやその効果についてはまだ不明な点が 多く, また設計法も確立していないのが現状である.

砂質地山トンネルの挙動についての研究としては, 村 山, 松岡 ${ }^{1)}{ }^{12}$ のアルミ棒積層体により地山をモデル化し た沈下床の実験がある.これにより沈下床とともに降下 するほぼア一チ形状の領域があること, またこの形状が

\footnotetext{
* 正会員 工博 フジタ工業 (株) 技術研究所 ( ₹223 横浜市港北区大棚町 74)

** 正会員 工修 フジタ工業 (株) 技術研究所 (同上)

*** 正会員 工博 フジタ工業 (株) 土木本部 ( ₹151 橴谷区干䭾ヶ谷 4-6-15)
}

広がりつつゆるみが上方に伝達されこのアーチの先端が 地表面に達するとゆるみ領域の幅はそれ以上広がらない ことが明らかになった。 また足立, 田村, 八嶋, 上野 はトンネル掘削による周辺地山への影響を調べるため に, トンネル横断面をモデル化したアルミ棒積層体地山 と直径可変のモデルトンネルを用いた模型試験を実施し ている. その結果, 被りが浅いと地表面まで大きな変位 が生じるが被りが深くなるとグランドアーチの形成によ り大きな変位を示す領域が縮小していくこと, また浅い トンネルと深いトンネルの区別は土被り $(H)$ とトンネル 径 $(D)$ の比でほぼ $H / D=2 \sim 3$ の間に境界がありそうな ことを明らかにした。これらの研究はトンネルの地山の 横断面の挙動を扱っていること, アルミ棒積層体地山と していることに特徴がある. しかし切羽周辺の挙動を調 ベるためにはトンネル縦断方向について考える必要があ ること, また補助工法の地山補強メカニズムやその効果 を調べるにはアルミ棒積層体でモデル化した地山では問 題があるように考えられる.

そこで本研究では切羽の安定化, 地表面沈下防止のた めに都市 NATM で採用されるボルトを用いた補助工法 の地山補強メカニズムとその効果を調べるために, 地山 材料として乾燥砂を用いてトンネル縦断部をモデル化し た模型試験を実施した.この模型試験の特徴は土被りが 
非常に浅いトンネルを想定していること $(H / D=1.0$ で，これは足立ら ${ }^{3)}$ の分類では浅いトンネルになる), 補助工法の効果を調べるためにある程度大きい模型（模 型でトンネルの直径に相当するものが $D=50 \mathrm{~cm})$ とし ていることである.

\section{2. 縦断トンネル土槽試験装置と試験方法}

使用した縦断トンネル土槽は図一1 に示すようにトン ネル切羽周辺の縦断部分を二次元的にモデル化したもの である.トンネル部分は長さ $50 \mathrm{~cm}$, 幅 $30 \mathrm{~cm}$, 高さ 50 $\mathrm{cm}$ のアクリル製の箱でモデル化した. モデルトンネル の高さ $50 \mathrm{~cm}$ は実際のトンネルでは掘削断面の直径あ るいは高さに相当するので，ここではこれをトンネル断 面の直径 $D$ と表示することにする. このトンネルは土 槽側面に取り付けられ，上・下面をガイド板とフラット ベアリングにより水平横方向のみに動くようにガイドさ れている.

この土槽では, トンネル先端面を図一1に示すように ガイド板(長さ $25 \mathrm{~cm}$ ) の先端から $5 \mathrm{~cm}$ だけ出しておき, トンネル箱を水平方向に $L=5,10,20,30,40,50 \mathrm{~mm}$ と段階的に引き抜いてトンネル掘削状態を再現してい

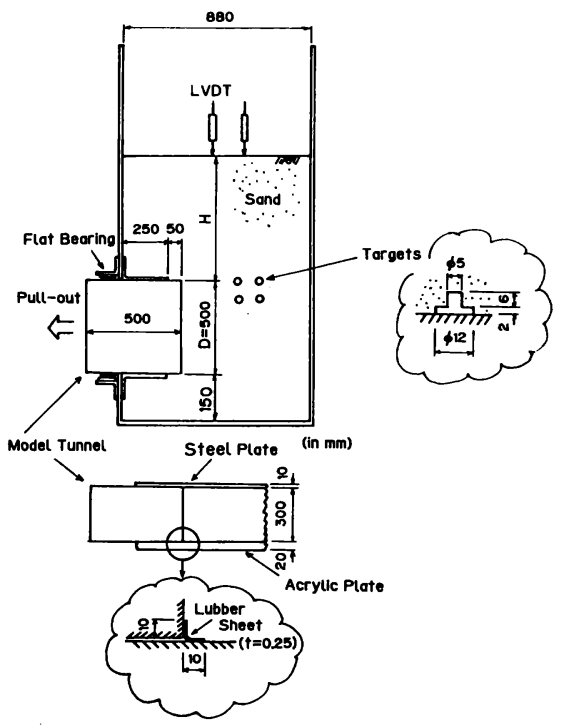

図一1＼cjkstart繸断トンネル土槽試験装置
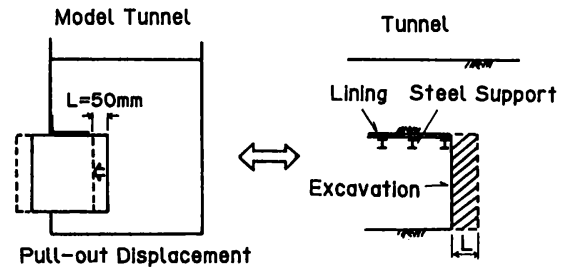

Pull-out Displacement

図一2＼cjkstart模型試験によるトンネル掘削の再現
る.この試験では地中の変位を把握するために実際には 発生しないような大きな変形を地山に与えている. 大変 形時の挙動は小変形時の挙動の延長上にあると考えられ るので，このような大変形を許す試験であっても実際の 地山挙動を推定することは十分可能であろう.このトン ネル引抜きは実際のトンネル掘削で考えると図一2に示 すように 1 区間だけ無支保状態で掘削を進めることに相 当しよう. 試験に使用した地山材料は浜岡砂で, この材 料の物理的特性と粒度曲線を図一3(a) に示してある. 図中には比較のために豊浦砂の粒度曲線も示してある. 浜岡砂の強度特性は三軸圧縮試験（飽和排水条件）によ り調べた．模型試験では地山の対象となる拘束圧領域が 低いことを考えて, 試験は拘束圧 $\sigma_{c}=\sigma_{3}=0.05 \sim 0.21$ $\mathrm{kgf} / \mathrm{cm}^{2}$ において実施した。試験結果を図一3(b) に示 してあるが, 図中の内部摩擦角 $\phi$ は粘着力成分を 0 と して

$$
\phi=\sin ^{-1}\left(\left(\sigma_{1}-\sigma_{3}\right)_{\max } /\left(\sigma_{1}+\sigma_{3}\right)_{\max }\right)
$$

より計算した.この図から拘束压 $\sigma_{3}=0.05 \sim 0.20 \mathrm{kgf} /$ $\mathrm{cm}^{2}$ の範囲では $\phi$ は拘束圧によらずほとんど一定である ことがわかる.

模型地山は空気乾燥状態にある砂を出口寸法が $3 \mathrm{~mm}$ $\times 280 \mathrm{~mm}$ のホッパーから高さ約 $80 \mathrm{~cm}$ で自由落下させ

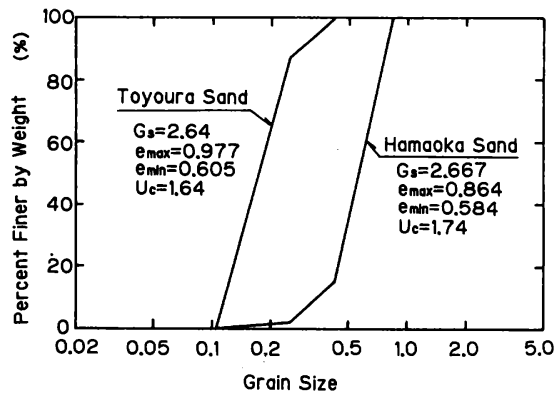

図一3(a) 地山材料の粒度曲線と物理的特性

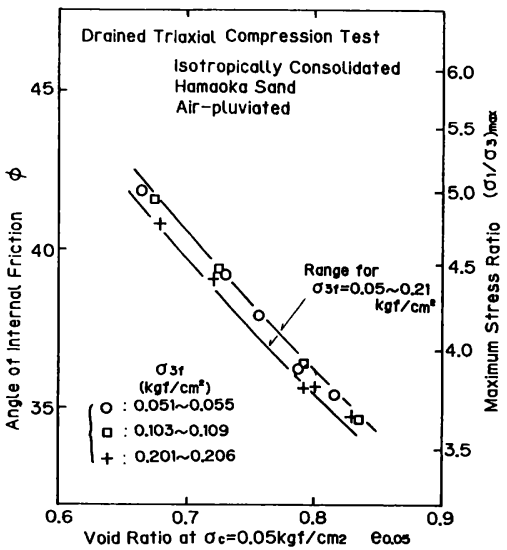

図一3(b) 地山材料の三軸圧縮試験結果 
て作製した。このときの地山の密度は $\rho_{d}=1.50 \sim 1.52$ $\mathrm{g} / \mathrm{cm}^{3}(e=0.75$ - 0.78$)$ である.このように砂を自由 落下させて堆積させると, 構造異方性のある地山になる ものと考えられる．模型地山を製作するときには地中変 位を測定するために図一1に示したように標点をほぼ 10 $\mathrm{cm} \times 10 \mathrm{~cm}$ の格子状に配置した。この標点は地山の変 位とともに移動するようにジュラルミンで作製したもの である. 地中变位はモデルトンネルを階段的に引き抜い たときの標点の移動を写真撮影し, 写真上の標点の位置 をデジタイザーで読み取ることにより测定した。地山の 地表面沈下は約 $10 \mathrm{~cm}$ 間隔で設置した変位計により測 定した。また地山の地中変位の状況が目視できるように $10 \mathrm{~cm}$ 層厚ごとに赤いチョークの粉を混ぜた砂の薄層を おいた.

本研究では地山材料として乾燥砂を使用しているが, これは以下の理由による．砂質地山中の都市トンネルは 地下水位を低下させ地山を不飽和状態にして掘削され る.このため, 砂質土であっても不飽和状態でのサクショ ンにより小さいながらも見掛けの粘着力が存在し, 地山 強度 $\left(\tau_{f}\right)$ は粘着力成分 $(c)$ 之摩擦成分 $(\sigma \tan \phi)$ から成 る $\left(\tau_{f}=c+\sigma \tan \phi\right)$. 模型試験において実物と同じ材 料をそのまま使用すると，模型地山はその縮尺に応じて 拘束压が小さくなるので地山の全強度成分のうちに占め る摩擦成分が小さくなり粘着力成分の占める割合が相対 的に大きい地山に，つまり砂質地山というより粘性土に 近い地山に相当することになってしまう.したがって,

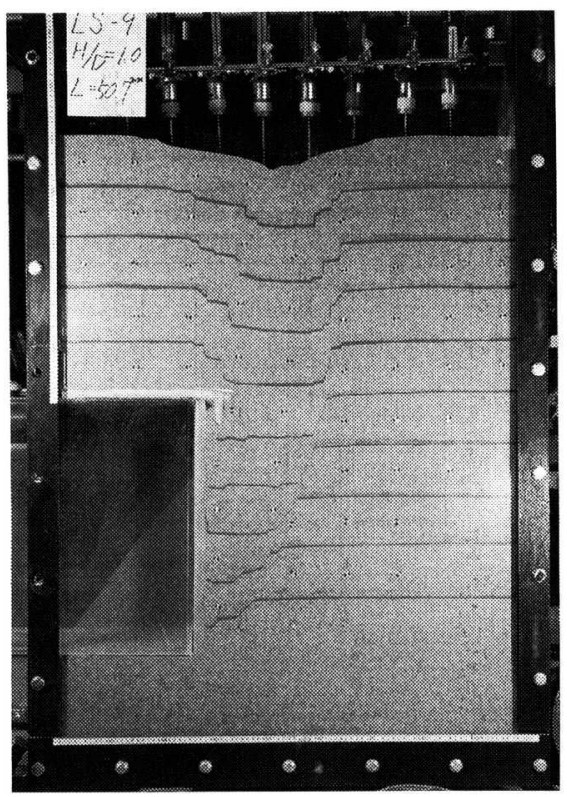

写真一1 地山の变形状況 $(H / D=1.0, L \doteqdot 50 \mathrm{~mm})$

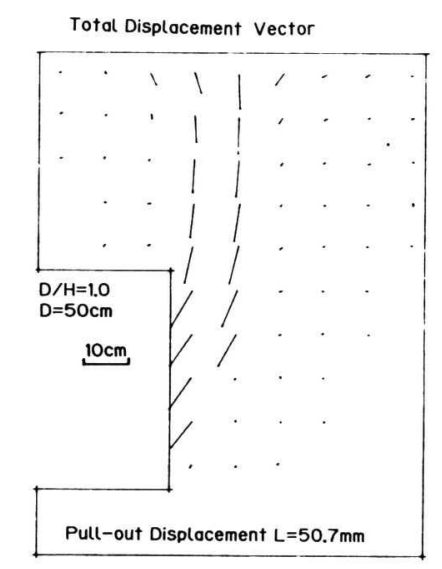

図一4 地中変位ベクトル $(L \fallingdotseq 50 \mathrm{~mm})$

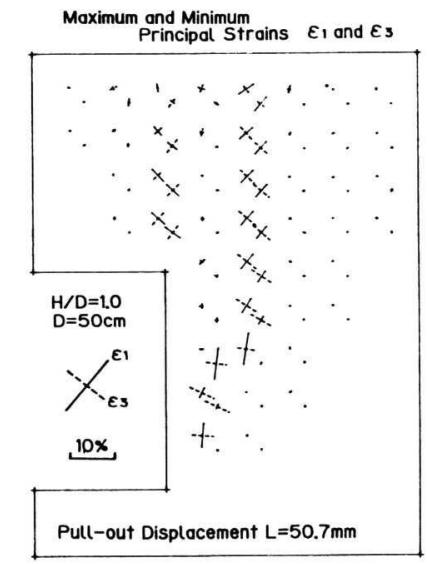

図一5 最大・最小主ひずみの大きさと方向

模型試験では粘着力成分のない乾燥砂を使用する方が夷 際の地山状況をモデル化できるものと考えられる。

\section{3. トンネル掘削が周辺地山に及ぼす影響}

写真一 1 に土被り $H$ とトンネルの直径 $D$ が同じ $H /$ $D=1.0$ の場合にトンネルを $L=50 \mathrm{~mm}$ だけ引き抜いた ときの地山の変形状況を示している. 図一4には写真一 1 から読み取った地中変位をべクトルで示してある。こ れらの写真とベクトル図からトンネルを引き抜くことに より生じた地中変位はある領域に限られ，明確なすべり 線により変形部分と未変形部分とに分けられていること がわかる。また地中変位は本試験のように土被りが小さ いとグランドアーチが形成されず切羽の変位がそのまま 地表面に伝達されることがわかる。

図一5には図一 4 の地中変位から計算した最大主ひず み $\left(\varepsilon_{1}\right)$ と最小主ひずみ $\left(\varepsilon_{3}\right)$ の大きさと方向を示してあ る.この図からひずみはすべり線部分に集中して生じて いるだけですべり線に聿まれた部分はほとんどひずみは 
生じていないこと,つまりすべり線に囲まれた部分はほ とんど変形せずにそのまま切羽部に向かってすべり落ち ていることがわかる. また地山が伸び変形をしている方 向 $\left(\varepsilon_{3}\right.$ 方向：土は伸び変形に対して弱い材料であるか ら特にこの方向に着目する) をみると, 切羽上方部の地 山は斜め方向に伸びているが, 切羽前方部ではほぼ水平 方向に伸びていることがわかる.

\section{4. 補助工法の地山補強メカニズム}

\section{（1） ボルトを使用した補助工法のモデル化}

ボルトを使用した補助工法の地山補強メカニズムを調 ベるために, 以下に示すように斜めボルト工法, 鏡止め ボルト工法, 縫地ボルト工法の 3 種類についてモデル化 した.

\section{a) 斜めボルト工法ボルト}

補強材として直径 $2 \mathrm{~mm}$ の針金に砂粒子を付着させ, これを図一6に示すようにある一定間隔 $(\Delta w)$ で支保工 代わりのガイド板先端に固定し, 角度 $(\theta)$ を変えて斜め
方向に打設した。

b）鏡止めボルト工法

補強材は図一7に示すように直径 $2 \mathrm{~mm}$ の針金に砂粒 子を付着させて，この一端にベアリングプレートをモデ ル化した一辺 $2 \mathrm{~cm}$ の正方形のボール紙（厚さ $1 \mathrm{~mm}$ ) を付けて作製した。これをモデルトンネルの鏡面に一定 間隔 $(\Delta w \times \Delta h)$ で水平に打設した。

c) 縫地ボルト工法

補強材は直径 $2 \mathrm{~mm}$ の針金に砂粒子を付着させ,これ を長さ $50 \mathrm{~cm}$ にして図一 8 に示すように地表面から一定 間隔 $(\Delta l \times \Delta w)$ でトンネル切羽面の前後 $20 \mathrm{~cm}, 40 \mathrm{~cm}$ の範囲に鉛直あるいは斜め方向に打設した.

\section{（2）斜めボルト工法の効果}

図一 $9(\mathrm{a}) \sim(\mathrm{d})$ に長さ $L_{R}=60 \mathrm{~cm}$ の補強材を，間隔 $\Delta w=1.0 \mathrm{~cm}$ で角度 $\theta=0^{\circ}, 15^{\circ}, 30^{\circ}, 45^{\circ}$ と変えて打設 して, トンネルを $L=50 \mathrm{~mm}$ だけ引き抜いたときに生 じた地中変位ベクトルを示してある。これらより，ボル トを打設したことにより地山の変位状況にかなりの差が
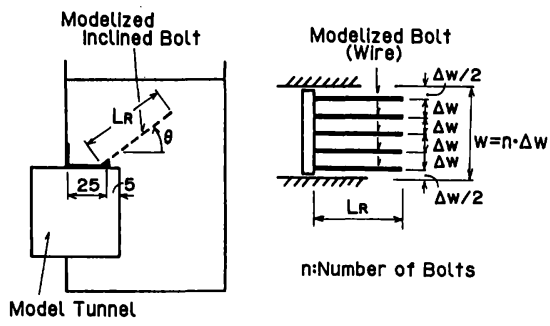

図一6 モデル化した斜めボルト工法
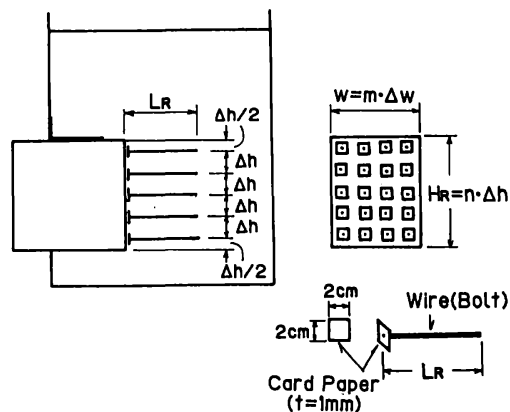

图一7 モデル化した鏡止めボルト工法
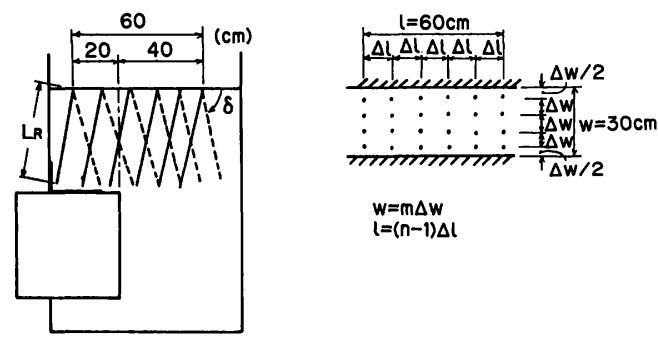

図一8 モデル化した繾地ボルト工法

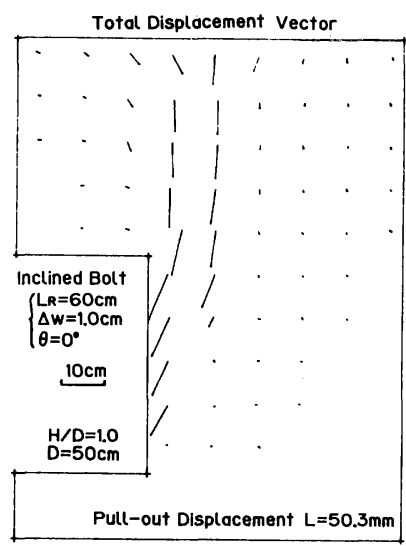

(a) $\theta=0^{\circ}$

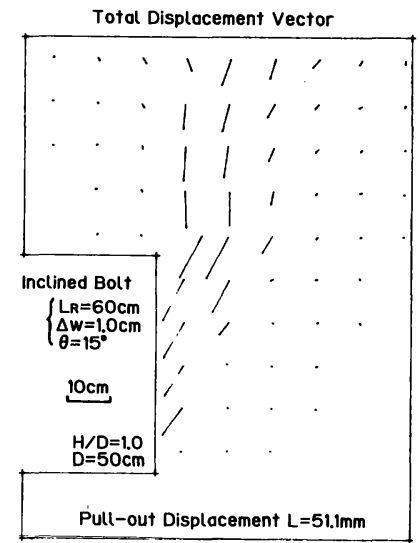

(b) $\theta=15^{\circ}$

図一9 地中変位ベクトル (斜めボルト， $\left.L_{R}=60 \mathrm{~cm}\right)$ 


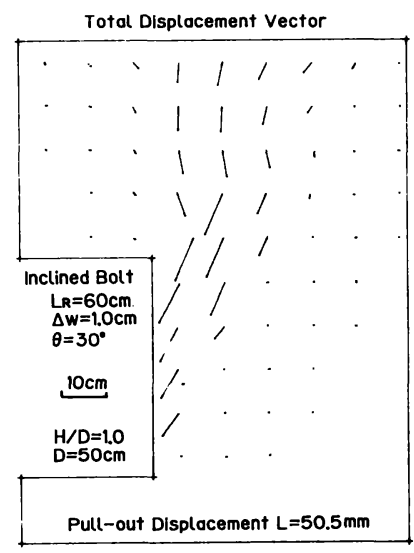

(c) $\theta=30^{\circ}$

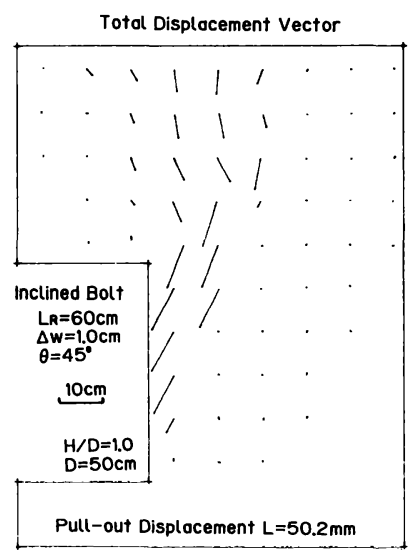

(d) $\theta=45^{\circ}$

図一9 地中変位ベクトル (斜めボルト, $L_{R}=60 \mathrm{~cm}$ )

生じ, 変位領域が広くなることがわかる.また図一10(a) にはトンネル引抜きに伴う地表面沈下を示してある.こ れらの図から補強材を水平に打設しても地中変位防止, 地表面沈下防止にはほとんど効果はないが, 斜め方向に 打設すれば効果的であることがわかる.また $\theta=15$ $30^{\circ}$ の範囲に最も効果の大きい打設角度があるようであ る. 砂粒子を付着させてない針金と, 付着させてある針 金をそれぞれ角度 $\theta=30^{\circ}$, 間隔 $\Delta w=1 \mathrm{~cm}$ で打設した ときの試験結果を図一10(b) に示してある.この図か ら砂粒子が付着してない針金は, 全く効果がないわけで はないが, その効果は砂粒子が付着している針金に比べ てかなり小さいことがわかる.このことはボルトによる 地山の補強効果にボルトと地山との摩擦が重要な役割を 果たしていることを示しているといえる. 図一11には 補強材長さの影響を調べるために, 角度 $\theta=30^{\circ}$ で長さ を $L_{R}=15,30,60 \mathrm{~cm}$ と変えて補強材を打設したときの トンネル引抜きに伴う地表面沈下を示してある. この図 から補強材長さが大きいほど地表面沈下防止に効果的で

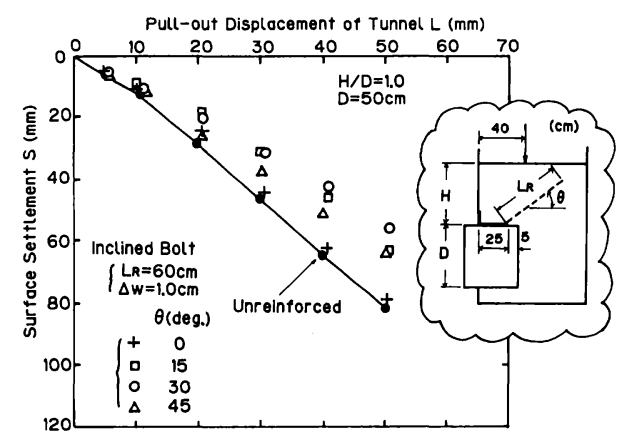

図一10(a) トンネル引抜きに伴う地表面沈下（斜めボルト， $L_{R}=60 \mathrm{~cm}$ )

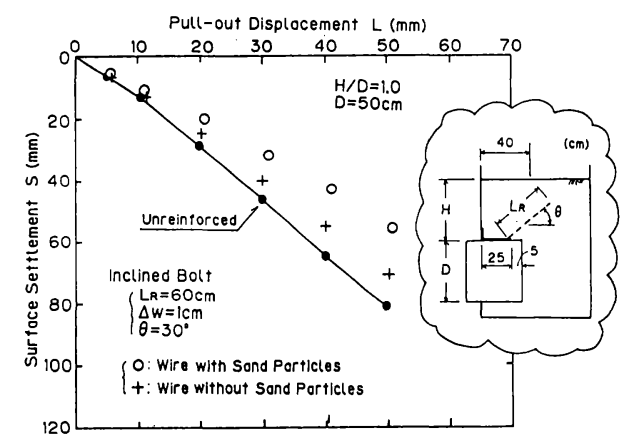

図一10(b) トンネル引抜きに伴う地表面沈下 (ボルトの摩擦 の影響）

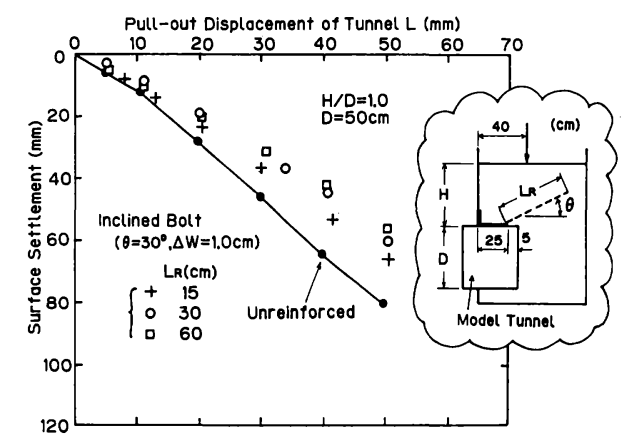

図一11 トンネル引抜きに伴う地表面沈下 (斜めボルト, $\theta=30^{\circ}$ )

あるが，この長さの影響は補強材角度の影響ほど大きく はなく補強材の打設角度の方がより重要な要素であるこ とがわかる.

以上のように,斜め方向に打設した補強材が地中変位, 地表面沈下を小さくするのに効果があることと図一 5 に 示したようにトンネル上方部の地山が伸びていることと は無関係ではないだろう。つまり地山が伸び変形をする 方向に補強材を打設すると, 補強材と地山の間の相対変 位が大きいので両者に働く摩擦力が最も大きくボルトが 地山の伸び変形を効果的に拘束するものと考えられる.

ボルトのような補強材をすべり線を横切るように打設 


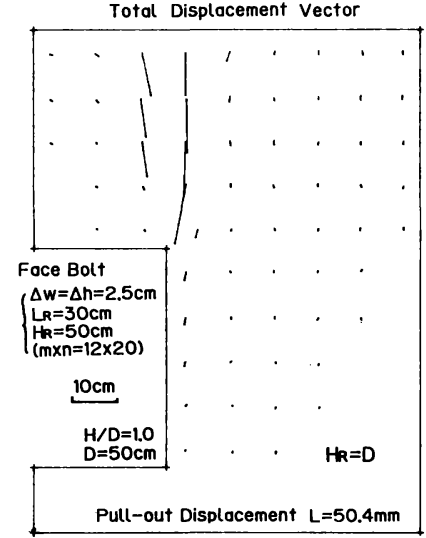

(a) $\Delta w=\Delta h=2.5 \mathrm{~cm}$

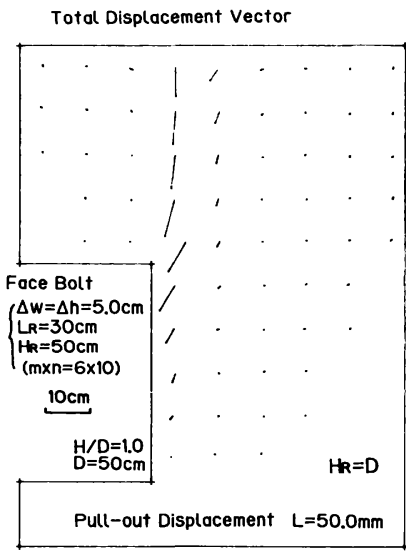

(b) $\Delta w=\Delta h=5.0 \mathrm{~cm}$

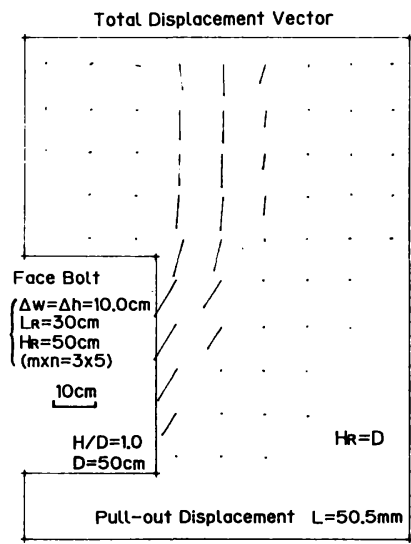

(c) $\Delta w=\Delta h=10.0 \mathrm{~cm}$

図一12 地中変位ベクトル (鏡止めボルト, $\left.H_{R}=D\right)$

したときにはボルト自身の剛性による補強効果も考えら れるが，図一10(a) にあるように補強材が地山が伸びる 方向ではなく，すべり線を横切るように打設した角度 $\theta$ $=0^{\circ}$ の場合にほとんど効果がないことから，ボルトの

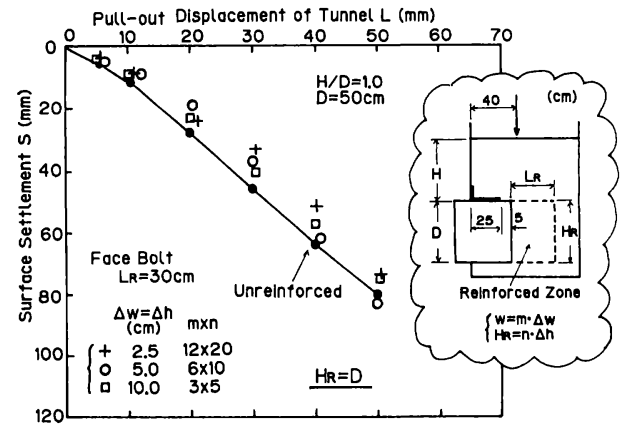

図一13 トンネル引抜きに伴う地表面沈下

(鏡止めボルト, $\left.H_{R}=D\right)$

剛性による効果は小さいといえよう.

\section{（3）鏡止めボルト工法の効果}

図一12(a) （c）に鏡部全面 $\left(H_{R}=D\right)$ に長さ $L_{R}=30$ $\mathrm{cm}$ の補強材を間隔を $\Delta w=\Delta h=2.5,5.0,10.0 \mathrm{~cm}$ と 変えて打設して，トンネルを $L=50 \mathrm{~mm}$ だけ引き抜い たときの地中変位ベクトルを示してある.これらの図か ら鏡止めボルトにより鏡部の変形は小さくなっているこ と, 鏡部の安定にこの種のボルトが非常に効果的である ことがわかる. 特に補強材間隔の小さい $\Delta w=\Delta h=2.5$ $\mathrm{cm}$ と $5.0 \mathrm{~cm}$ の場合にはそうである.ただし，鏡部の 変形が小さいのでトンネル引抜きにより生じた空間を埋 めるように天端部の地山がこの部分に変位し, 天端部に 局部的に大きな変位が生じている.このことはトンネル 引抜きに伴う地表面沈下を示す図一13からもわかり， 必ずしも鏡止めボルトによる鏡部の安定がそのまま地表 面沈下防止につながらないようである．実際のトンネル ではこのような大変形を与えることなく支保を施しなが ら掘削するので，ここでみられるような局部的な沈下現 象は生じないように考えられる.むしろ鏡部の安定にこ の種のボルトの打設が非常に有効であることに注目すべ きであろう.

以上のように水平方向に打設した鏡止めボルトが鏡部 の安定に効果的なのは，図一5に示したように鏡部の伸 び変形の方向がほぼ水平であるからこの方向にボルトを 打設するとボルトと地山との間に生じる摩擦力が最も大 きく, ボルトにより地山の変形が拘束されるためと考え られる.

\section{（4）縫地ボルト}

図一14(a)，(b) に角度を $\delta=90^{\circ}$ と $60^{\circ}$ と変えて補強 材を打設したときの地中変位ベクトルを示してある．ま た図一15にはトンネル引抜きに伴う地表面沈下を示し てある。これらの図から鉛直方向に打設した縫地ボルト はほとんど効果はないが，斜めに打設した場合には地中 変位, 地表面沈下を小さくする効果があることがわかる. 


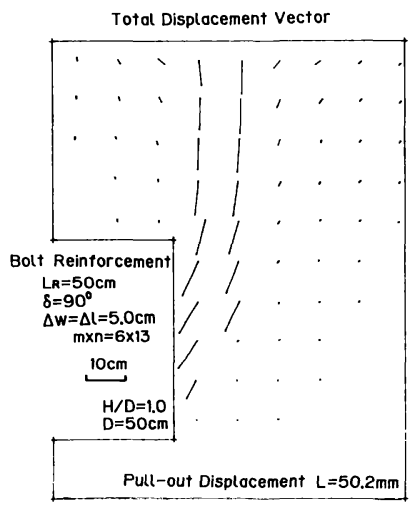

(a) $\delta=90^{\circ}$

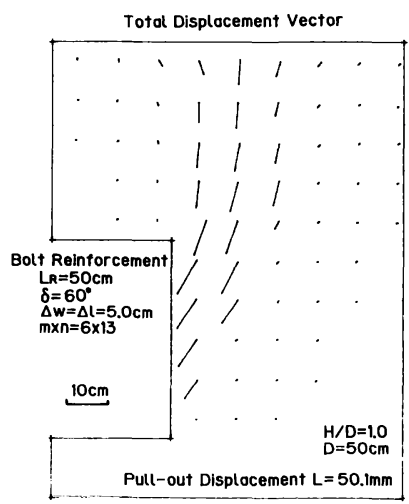

(b) $\delta=60^{\circ}$

図一14 地中変位ベクトル（縫地ボルト， $\left.L_{R}=50 \mathrm{~cm}\right)$

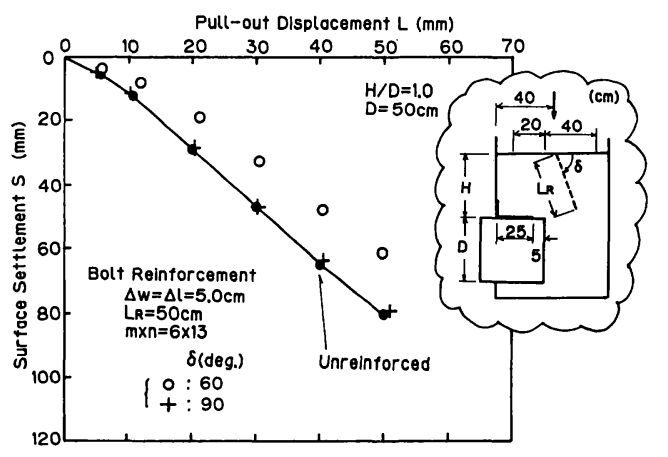

図一15 トンネル引抜きに伴う地表面沈下（縫地ボルト， $L_{R}=$ $50 \mathrm{~cm}$ )

これは斜めボルトと同様に，切羽上方部の地山の斜め方 向の伸び変形をボルトが地山との摩擦により拘束するた めと考えられる.

\section{5. ボルトの効果}

以上のようにボルトを使用した補助工法はボルトを地 山が伸び変形をする方向に打設すると地山の補強に効果 的であることがわかった。このボルトによる補助効果は
ボルトと地山との摩擦による地山の伸び変形の拘束によ るものであるが，これは補強土の引張補強材による補強 原理")と同じである。つまり地山内に何もないときに生 じる最小主ひずみ $\left(\varepsilon_{3}\right)$ 方向にボルトを打設すると最も補 強効果が大きく，この場合にはボルトには引張力のみが 作用する.ここではこのボルトの効果の意味について考 えてみる.

トンネルを掘削することは, その地山中の応力を解放 すること, つまり地山に除荷の応力変化を与えることに 相当しよう (図一16).このとき地山の伸び変形方向に(最 小主ひずみ $\varepsilon_{3}$ 方向）に打設されたボルトの効果をボル 卜を含む地山要素から考えてみる. 図一17 に示すよう に地山要素 ( abcd) に作用する応力のうち, ボルトも 含めた要素全体に作用する平均的な応力 $\left(\sigma_{1 a v}, \sigma_{3 a v}\right)$ と, ボルト付近に作用する部分的な応力 $\left(\sigma_{1 e}, \sigma_{3 e}\right)$ とに分け て考える. ボルトは最小主応力方向に打設されているの で, 地山との摩擦によりボルトには引張力 $T$ が作用し この方向の変形を拘束するので, この方向のボルト付近 の応力 $\sigma_{3 e}$ は要素の平均的な応力 $\sigma_{3 a v}$ とは等しくならな い. 一方, これと直交する方向ではボルトにより拘束さ れないのでこの方向の応力, すなわち最大主応力はボル トによりなんら影響を受けないので平均的応力と部分的 な応力とは互いに等しく,

$$
\sigma_{1 a v}=\sigma_{1 e}, \quad \sigma_{3 a v} \neq \sigma_{3 e}
$$

である. 図一17から地山要素に外部より加わるのは平 均的な応力とボルトによる引張力で, これにつり合う部 分的な応力との水平方向の力のつり合いを考えると, $\sigma_{3 e} \Delta h=\sigma_{3 a v} \Delta h+T$ となるから,

$$
\sigma_{3 a v}=\sigma_{3 e}-T / \Delta h
$$

が得られる. トンネルを掘削することは切羽の平均的な
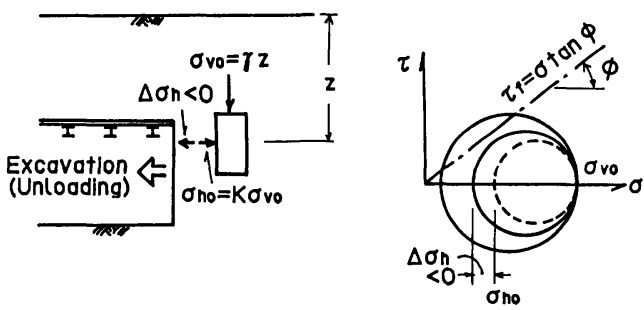

図一16 トンネル掘削による応力変化

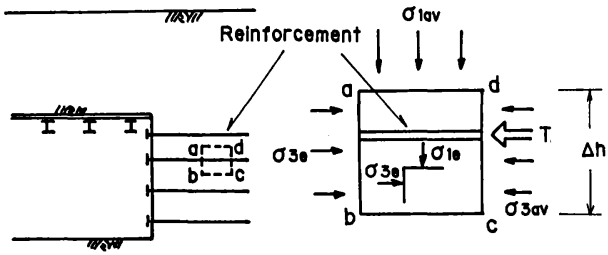

図一17 地山要素の応力状態 


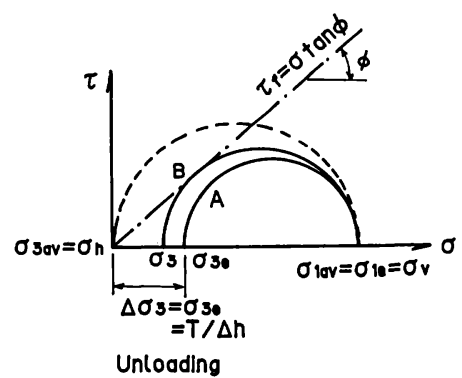

図一18 地山要素のトンネル掘削による応力変化

最小主応力を $\sigma_{3 a v}=\sigma_{h} \rightarrow 0$ にすることに相当するが, こ のときの平均的な応力の変化を Mohr の応力円で表わす と図一18 の点線の円になる．またボルト周辺の部分的 な応力は式 (2) から

$\sigma_{3 e}=T / \Delta h$

となり，ボルトと地山との摩擦により見掛け上拘束圧が 増加していることになり，この場合の Mohr 円は円Aに なる．これより平均的な応力では Mohr 円が破壊包絡線 を越えて破壊状態になっているが，ボル卜周辺の部分的 な応力状態はボルトと地山の摩擦に起因する見掛けの拘 束圧の増加 $\left(\Delta \sigma_{3}=\sigma_{3 e}=T / \Delta h\right)$ により必ずしも破壊状 態になっていない。 つまり地山応力の Mohr 円（円B） が破壊包絡線に接するときの条件（破壊条件）

$$
R_{f}=\sigma_{1} / \sigma_{3}(=(1+\sin \phi) /(1-\sin \phi))
$$

より求まる $\sigma_{3}=\sigma_{1 a v} / R_{f}$ よりも, 見掛けの拘束圧の増加 分 $\Delta \sigma_{3}=\sigma_{3 e}=T / \Delta h$ が大きく

$$
\Delta \sigma_{3}>\sigma_{3}
$$

であれば破壊状態にならず地山は安定していることにな る.このように補助工法のボルトは周辺地山との摩擦に より見掛け上の拘束圧を増加させる効果をもっており， このためボルト周辺の地山は剛性が大きくなり一体化し たようになるものと考えられる.

\section{6. 結 論}

未固結な砂質地山を都市 NATM でトンネルを掘削す るときに切羽の安定化，地表面沈下防止のために採用さ
れる，ボルトを用いた補助工法の地山補強メカニズムと その効果を土被りが非常に浅いトンネル $(H / D=1.0)$ を想定した模型試験により調べた結果以下のことがわ かった。

（1）トンネル引抜きにより切羽周辺の地山の破壊は 局部的に生じ，すべり線により変形部分と未変形部分に 明確に分けられる。そしてすべり線に囲まれた部分はほ とんよ゙変形せずにそのまま切羽に向かってすべり落ちて いる.

（2）トンネル引抜きによる地山の伸び変形をする方 向をみると，切羽上方部分は斜め方向に伸びているが, 切羽前方部分（鏡部）はほぼ水平方向に伸びる傾向にあ る.

（3）ボルトを使用した補助工法は，ボルトの打設を する方向により効果が大きく異なり，地山が伸び変形を する方向に打設すると効果的である。このボルトによる 補強効果はボルトと地山之の間に発生する摩擦による地 山の伸び変形の拘束によるものである.

ここでは地山にかなりの変形を許して地山が崩壊状態 にあるような場合を想定した試験となっている。この状 態が砂質地山のトンネル掘削の状況を完全に再現しては いないが，ボルトを用いた補助工法の基本的な地山補強 メカニズムは調べられたように考えている.

\section{参 考 文 献}

1）村山朔郎・松岡 元：粒状土地盤の局部沈下現象につい て, 土木学会論文報告集, 第 172 号, pp. 31 41, 1969.

2）村山朔郎・松岡 元：砂質土中のトンネル土圧に関する 基礎的研究, 土木学会論文報告集, 第 187 号, pp. 95 108, 1971.

3）足立紀尚・田村 武・八嶋 厚 -上野 洋：砂質地山卜 ンネルの挙動と解析に関する研究, 土木学会論文集, 第 356 号, III-3, pp. 129 136, 1985.

4）龍岡文夫 · 金藤浩司 · 三木五三郎 · 生原 修 · 浜田英 治・佐藤剛司：引張り補強材による砂の補強についての 基礎的研究, 土と基礎, Vol. 31, No. 9, pp. 11 19, 1983.

(1988.6.10 • 受付) 